Check for updates

Cite this: RSC Adv., 2021, 11, 3190

Received 24th December 2020

Accepted 5th January 2021

DOI: 10.1039/dOra10814f

rsc.li/rsc-advances

\section{Structure and electrochemical activity of nickel aluminium fluoride nanosheets during urea electro-oxidation in an alkaline solution $\uparrow$}

\author{
Saba A. Aladeemy, ${ }^{\text {ab }}$ Abdullah M. Al-Mayouf, (D) ab Mabrook S. Amer, ${ }^{a}$ Nouf H. Alotaibi, ${ }^{a}$ \\ Mark T. Weller ${ }^{c}$ and Mohamed A. Ghanem (D) *a
}

\begin{abstract}
An electrocatalyst of potassium nickel aluminium hexafluoride $\left(\mathrm{KNiAlF}_{6}\right)$ nanosheets has been prepared using solid-phase synthesis at $900{ }^{\circ} \mathrm{C}$. X-ray diffraction, scanning electron microscopy, and conductivity studies confirmed the formation of $\mathrm{KNiAlF}_{6}$ nanosheets having a cubic defect pyrochlore structure with an average thickness of $60-70 \mathrm{~nm}$ and conductivity of $1.297 \times 10^{3} \mathrm{~S} \mathrm{~m}^{-1}$. The electrochemical catalytic activity of the $\mathrm{KNiAlF}_{6}$ nanosheets was investigated for urea oxidation in alkaline solution. The results show that the $\mathrm{KNiAlF}_{6}$ nanosheets exhibit a mass activity of $\sim 395 \mathrm{~mA} \mathrm{~cm} \mathrm{mg}^{-1}$ at $1.65 \mathrm{~V}$ vs. HRE, a reaction activation energy of $4.02 \mathrm{~kJ} \mathrm{~mol}^{-1}$. Tafel slope of $22 \mathrm{mV} \mathrm{dec}^{-1}$ and an oxidation onset potential of $\sim 1.35 \mathrm{~V}$ vs. HRE which is a significant enhancement for urea oxidation when compared with both bulk $\mathrm{Ni}(\mathrm{OH})_{2}$ and nickel hydroxide-based catalysts published in the literature. Chronoamperometry and impedance analysis of the $\mathrm{KNiAlF}_{6}$ nanosheets reveal lower charge transfer resistance and long-term stability during the prolonged urea electro-oxidation process, particularly at $60^{\circ} \mathrm{C}$. After an extended urea electrolysis process, the structure and morphology of the $\mathrm{KNiAlF}_{6}$ nanosheets were significantly changed due to partial transformation to $\mathrm{Ni}(\mathrm{OH})_{2}$ but the electrochemical activity was sustained. The enhanced electrochemical surface area and the replacement of nickel in the lattice by aluminium make $\mathrm{KNiAlF}_{6}$ nanosheets highly active electrocatalysts for urea oxidation in alkaline solution.
\end{abstract}

\section{Introduction}

In recent years, global energy demands have been increased due to worldwide economic growth, and alternative sustainable, clean, and inexpensive energy sources are highly required. Several small molecules including hydrogen, methanol, ethanol, and urea have been regarded as attractive alternative clean, inexpensive, and sustainable energy sources with great potential to replace fossil fuels and minimize the emission of greenhouse gases. ${ }^{1-7}$ In particular, urea and urea-rich wastewater have been identified as alternative fuels for hydrogen production in alkaline solution via the urea electrolysis process. ${ }^{5-13}$ The electro-oxidation reaction of urea in alkaline media has the benefits of denitrifying wastewater at the anode and $\sim 70 \%$ cheaper hydrogen production at the cathode when compared to water electrolysis. ${ }^{8-13}$

${ }^{a}$ Electrochemical Sciences Research Chair (ESRC), Chemistry Department, King Saud University, 11451 Riyadh, Saudi Arabia. E-mail: mghanem@ksu.edu.sa; Fax: +96614675992; Tel: +966 114670405

${ }^{b}$ K. A. CAR Energy Research and Innovation Center at Riyadh, Saudi Arabia ${ }^{{ }^{C}}$ Chemistry Department, Cardiff University, Cardiff, CF10 3AT, UK

$\dagger$ Electronic supplementary information (ESI) available. See DOI: 10.1039/d0ra10814f
It is well documented that low-cost nickel-based catalysts are very active electrocatalysts for urea electrolysis conducted in an alkaline solution, ${ }^{8-13}$ which has led to the development of the direct conversion of urine and urea into pure hydrogen as well as direct urea fuel cell applications. ${ }^{\mathbf{1 0 - 1 2}}$ Wastewater contains an average urea concentration of $0.33 \mathrm{M}$, which can be electrochemically oxidized using a nickel catalyst at a standard electrode potential of $-0.46 \mathrm{~V} v s$. SHE (eqn (1)), while $\mathrm{Ni}(\mathrm{OH})_{2}$ is converted into $\mathrm{NiOOH}$ at $0.49 \mathrm{~V}$ (eqn (2)). On the other hand, water is reduced at the cathode $(-0.83 \mathrm{~V})$ (eqn (3)) and the overall reaction shown in eqn (4) occurs at $0.37 \mathrm{~V}$, which is significantly lower than the thermodynamic potential required for water electrolysis $(1.23 \mathrm{~V}){ }^{8}$

Anode reaction:

$$
\begin{aligned}
& 6 \mathrm{Ni}(\mathrm{OH})_{2}(\mathrm{~s})+6 \mathrm{OH}^{-} \rightleftharpoons 6 \mathrm{NiOOH}(\mathrm{s})+6 \mathrm{H}_{2} \mathrm{O}(\mathrm{l})+6 \mathrm{e}^{-} \\
& \mathrm{CO}\left(\mathrm{NH}_{2}\right)_{2}(\mathrm{aq})+6 \mathrm{Ni}(\mathrm{OOH})+\mathrm{H}_{2} \mathrm{O} \rightarrow \\
& \mathrm{N}_{2}(\mathrm{~g})+\mathrm{CO}_{2}(\mathrm{~g})+6 \mathrm{Ni}(\mathrm{OH})_{2}
\end{aligned}
$$

Cathode reaction:

$$
6 \mathrm{H}_{2} \mathrm{O}(\mathrm{l})+6 \mathrm{e}^{-} \rightarrow 3 \mathrm{H}_{2}(\mathrm{~g})+6 \mathrm{OH}^{-}
$$

Overall reaction: 


$$
\mathrm{CO}\left(\mathrm{NH}_{2}\right)_{2}(\mathrm{aq})+\mathrm{H}_{2} \mathrm{O}(\mathrm{l}) \rightarrow \mathrm{N}_{2}(\mathrm{~g})+3 \mathrm{H}_{2}(\mathrm{~g})+\mathrm{CO}_{2}(\mathrm{~g})
$$

However, there are many challenges including the availability of abundant inexpensive catalysts, relatively slow reaction kinetics, and frequent poisoning of the catalyst, which limit the application of urea as fuel for large-scale hydrogen production..$^{8-13}$ Therefore, the use of abundant and very active catalysts may overcome these challenges by increasing the activity and allowing fast reaction kinetics. Consequently, nickel-based materials have been widely developed for use in electrochemical energy cells utilizing small organic molecules such as methanol ${ }^{4,14-16}$ and urea $^{3,8-13}$ as fuel. However, pure nickel electrocatalysts have drawbacks such as high electrolysis over-potential and unstable oxidation current. Thus, to overcome these problems various combinations of nickel with other metals have been investigated in the urea electro-oxidation reaction., ${ }^{9,12,17-21}$ These combinations present the opportunity to exploit both the independent and synergistic properties of the different metals used to tailor the geometric and electronic environment of the active sites to yield higher catalytic efficiencies. The partial replacement of nickel in the lattice of nickel hydroxide by aluminium, ${ }^{22-24}$ cobalt, ${ }^{25}$ iron, ${ }^{26}$ and zinc ${ }^{27}$ ions has been widely reported, which show a significant enhancement in the reversibility of the electrochemical reaction, higher proton diffusion coefficient, lower electrochemical impedance, higher specific capacity, and enhanced cycle stability. Moreover, nanostructured nickel-based catalysts and those supported on carbon-based materials have been investigated to enhance the kinetics and activity of the urea electrooxidation reaction in alkaline media. ${ }^{3,17,22,28-31}$ Wang et al. ${ }^{17}$ have synthesized a variety of graphene-nickel nanocomposites using a one-step electrochemical reduction process, which was developed as electrocatalysts for hydrogen production via the electro-oxidation of urea. They pointed out that these nanocomposites diminish the surface blockage observed with other catalysts and improve the current density of the reaction. In related work, Botte et al. ${ }^{8}$ synthesized two-dimensional (2D) nickel hydroxide nanosheets by exfoliating surfactant intercalated layered nickel hydroxides for use in the urea electrooxidation reaction. The $2 \mathrm{D}$ nanosheets exhibit a $100 \mathrm{mV}$ lower overpotential and enhanced in current density during the urea electro-oxidation reaction in an alkaline solution to produce hydrogen and the decomposition of urea into non-toxic products. Lin et al. ${ }^{28}$ prepared single-layered (SL) $\alpha-\mathrm{Ni}(\mathrm{OH})_{2}$ nanosheets on carbon cloth $\left(\mathrm{SL}-\alpha-\mathrm{Ni}(\mathrm{OH})_{2} \mathrm{NS} / \mathrm{CC}\right)$ using a methanoldirected one-step growth process, which was employed as an anode in the electrocatalytic oxidation of urea in an alkaline solution to enhance the production of hydrogen at the cathode. The results revealed that nanowalls consisting of the SL- $\alpha-$ $\mathrm{Ni}(\mathrm{OH})_{2} \mathrm{NS}$ with a thickness of $0.8 \mathrm{~nm}$ fully covered the carbon cloth support and a urea oxidation current density of $436.4 \mathrm{~mA}$ $\mathrm{cm}^{-2}$ at $0.5 \mathrm{~V} v s . \mathrm{Ag} / \mathrm{AgCl}$ was achieved. Besides, Ghanem et al. ${ }^{32}$ have prepared nickel hydroxide nanoflakes $\left(\mathrm{Ni}(\mathrm{OH})_{2}-\mathrm{NF}\right)$ via the chemical deposition and in situ exfoliation of nickel hydroxide layers confined in an aqueous domain of a liquid crystalline hexagonal template consisting of Brij ${ }^{\circledR 78}$. They also confirmed the formation of $\alpha-\mathrm{Ni}(\mathrm{OH})_{2}$ nanoflakes with a thickness of 2-3 nm and a surface area of $450 \mathrm{~m}^{2} \mathrm{~g}^{-1}$. The asobtained $\mathrm{Ni}(\mathrm{OH})_{2}-\mathrm{NF}$ catalyst exhibits superior activity with a $>10$-fold increase in the activity than the bare-Ni deposit observed during the reaction of urea performed in an alkaline electrolyte. This was attributed to the superficial enhancement of the electroactive surface area of $\mathrm{Ni}(\mathrm{OH})_{2}-\mathrm{NF}$. Various compositions of spinel nickel manganese oxides catalysts including $\mathrm{NiMn}_{2} \mathrm{O}_{4}, \mathrm{Ni}_{1.5} \mathrm{Mn}_{1.5} \mathrm{O}_{4}$, and $\mathrm{MnNi}_{2} \mathrm{O}_{4}$ have been synthesized by Periyasamy et al. ${ }^{18}$ using a simple template-free hydrothermal route followed by thermal treatment under an air atmosphere at $800{ }^{\circ} \mathrm{C}$ for use in the urea oxidation reaction. Their study indicated that the $\mathrm{Ni}_{1.5} \mathrm{Mn}_{1.5} \mathrm{O}_{4}$ catalyst showed the best performance toward urea electro-oxidation, in which the current density reached $6.9 \mathrm{~mA} \mathrm{~cm}{ }^{-2}$ at $0.29 \mathrm{~V} v s$. Ag/AgCl.

Taking the advantages of the improved electrochemical reaction reactivity and cycle stability observed upon replacing nickel in the lattice with aluminium, ${ }^{22-24}$ this work reports the synthesis and characterization of a new electrocatalyst of $\mathrm{KNiAlF}_{6}$ nanosheets and its electrochemical activity towards the urea oxidation reaction conducted in an alkaline solution. The results with the $\mathrm{KNiAlF}_{6}$ nanosheets are compared with those of a spherical bulk $\mathrm{Ni}(\mathrm{OH})_{2}$ catalyst in terms of the crystal structure, morphology, conductivity, electrochemical activity, and stability for the electro-oxidation of urea.

\section{Experimental}

\section{Materials}

The nanostructured nickel-based catalyst was prepared using thermal solid-phase synthesis, whereas the bulk material was directly produced at room temperature. Nickel chloride hexahydrate $\left(\mathrm{NiCl}_{2} \cdot 6 \mathrm{H}_{2} \mathrm{O}\right)\left(M_{\mathrm{w}}=321.6 \mathrm{~g} \cdot \mathrm{mol}^{-1}, 99.0 \%\right)$ was purchased from Alfa Aesar. Potassium hydrogen fluoride $\left(\mathrm{KHF}_{2}\right)$ $\left(M_{\mathrm{w}}=78.10 \mathrm{~g} \mathrm{~mol}{ }^{-1}, 99.9 \%\right)$, nickel fluoride $\left(\mathrm{NiF}_{2}\right)\left(M_{\mathrm{w}}=\right.$ $\left.96.69 \mathrm{~g} \mathrm{~mol}^{-1}, 99.9 \%\right)$, and aluminium fluoride $\left(\mathrm{AlF}_{3}\right)\left(M_{\mathrm{w}}=\right.$ $\left.83.97 \mathrm{~g} \mathrm{~mol}^{-1}, 99.9 \%\right)$ were obtained from Sigma-Aldrich. Urea $\left(\mathrm{CO}\left(\mathrm{NH}_{2}\right)_{2}\right)\left(M_{\mathrm{w}}=60.06 \mathrm{~g} \mathrm{~mol}^{-1}\right)$ was purchased from AVONCHEM Corp. Potassium hydroxide pellets $\left(M_{\mathrm{w}}=56.11 \mathrm{~g} \mathrm{~mol}^{-1}\right.$, $85.0 \%)$ and isopropanol were purchased from the AnalaR group. Nafion solution $(10 \% \mathrm{w} / \mathrm{v})$ was obtained from Merck. All chemicals were used as received without any further purification. Carbon paper (CP, ®SIGRACET, grade GDL-24BC, SGL Technologies) was employed as the working electrode. Deionized water (DI, $18 \mathrm{M} \Omega$ resistivity) was used throughout this work and obtained using a Milli-Q ultrapure water purification system (18 M $\Omega$ resistivity).

\section{Catalysts synthesis}

The potassium nickel catalyst was prepared using solid-phase synthesis following the method described by Babel et al. ${ }^{33} \mathrm{~A}$ $1: 1: 1$ molar ratio of $\mathrm{KHF}_{2}(99,9 \%), \mathrm{NiF}_{2}(99.99 \%)$, and $\mathrm{AlF}_{3}$ (99.95\%) was ground and heated at $900{ }^{\circ} \mathrm{C}$ under a nitrogen atmosphere in a platinum crucible for $24 \mathrm{~h}$. The product was cooled to room temperature, reground, and heated to $900{ }^{\circ} \mathrm{C}$ for a further $72 \mathrm{~h}$. The product was lifted to cool down in an open atmosphere followed by washing several times with deionized 
water to remove the residual of the starting materials, then dried for overnight in an oven at $60{ }^{\circ} \mathrm{C}$. The bulk $\mathrm{Ni}(\mathrm{OH})_{2}$ catalyst was prepared by mixing $50 \mathrm{~mL}$ of $\mathrm{NiCl}_{2} \cdot 6 \mathrm{H}_{2} \mathrm{O}(0.1 \mathrm{M})$ solution with an excess of a concentrated solution of $\mathrm{KOH}$ and the formed precipitate of $\mathrm{Ni}(\mathrm{OH})_{2}$ was collected by filtration. Then, the solid was washed with distilled water several times and finally dried in an oven at $60{ }^{\circ} \mathrm{C}$ for overnight. For both catalysts, the conducting side of commercial carbon paper $(1.0$ $\mathrm{cm}^{2}, \mathrm{GDL}=248 \mathrm{C}$, $\left.{ }^{\circledR S I G R A C E T}\right)$ was used as the working electrode in the electrolysis cell. The catalyst ink was prepared by mixing $10 \mathrm{mg}$ of the $\mathrm{KNiAlF}_{6}$ nanosheets or reference catalyst with $1.0 \mathrm{~mL}$ of isopropanol/distilled water $(1: 1, \mathrm{v} / \mathrm{v})$ and added to $10 \mu \mathrm{L}$ of Nafion solution $(1.0 \mathrm{wt} \%)$ in a glass vial, and the resulting mixture sonicated for $15 \mathrm{~min}$ at room temperature. Various loadings $(50,100,200$, and $300 \mu \mathrm{g})$ of the as-obtained suspension were slowly cast onto the active area of the carbon paper substrate and dried were carried out using a hot air gun.

\section{Characterizations}

The nickel-based catalysts were characterized using powder XRD (PXRD), four-probes conductivity meter, and scanning electron microscopy (SEM) analysis. The surface morphology of the catalysts before and after use was characterized using SEM (FEI Quanta 250) operated at $15 \mathrm{kV}$. PXRD measurements were recorded on a MiniFlex-600 diffractometer (Rigaku) using $\mathrm{CuK}_{\alpha}$ irradiation operated at ( $40 \mathrm{KV}$ and $15 \mathrm{~mA}$ ) to investigate the crystal structure of the catalysts. Conductivity measurements were carried out using a four-point probe Ossila conductivity meter. An Auto-lab potentiostat/galvanostat ( $\mu 3$ Aut71211) instrument was used for all our electrochemical measurements. A three-electrode electrochemical cell consisting of a carbon paper ( ${ }^{\circledR S I G R A C E T}, \mathrm{GDL}=248 \mathrm{C}$ ) working electrode $\left(1.0 \mathrm{~cm}^{2}\right)$, platinum wire counter electrode, and $\mathrm{Ag} / \mathrm{AgCl}$ reference electrode fitted with a salt bridge was used during the measurements. The working potential was normalized to hydrogen reference electrode (HRE) using the equation $\left(E_{\mathrm{HRE}}=E_{\mathrm{Ag} / \mathrm{AgCl}}+\right.$ $0.198+0.059 \mathrm{pH})$. The electrochemical activities of the catalysts were examined in a $1.0 \mathrm{M} \mathrm{KOH}$ electrolyte in the absence and the presence of various urea concentration using cyclic voltammetry (CV), chronoamperometry (CA) and electrochemical impedance analysis techniques.

\section{Results and discussion}

\section{Characterization of the catalysts}

Fig. 1a shows the PXRD pattern obtained for the as-synthesized $\mathrm{KNiAlF}_{6}$ catalyst. The catalyst shows major peaks that match those previously reported for $\mathrm{KNiAlF}_{6}$ (JPC 01-072-1553) and adopts the cubic defect pyrochlore structure in the cubic space group of $F d \overline{3} m$ previously reported for this phase $(a=9.92 \AA) .{ }^{33}$ In this pyrochlore structure, $\mathrm{Ni}$ and $\mathrm{Al}$ are disordered on an octahedral site, $\left(\mathrm{Ni}_{0.5} \mathrm{Al}_{0.5}\right) \mathrm{F}_{6}$, and $\mathrm{K}^{+}$cations also have octahedral coordination to fluoride. As shown in the crystal structure model in Fig. 1b the structure can be considered as a modified pyrochlore structure $\left(\mathrm{AB}_{2} \mathrm{X}_{6}\right)$ and is constructed of chains of vertex linked $\left(\mathrm{Ni}_{0.5} \mathrm{Al}_{0.5}\right) \mathrm{F}_{6}$ octahedral orientated in layers with alternating orthogonal directions and potassium cations in the channels thereby formed. The small additional reflections in the X-ray pattern were attributed to minor impurities originating from the residual of starting materials which can be removed by washing using deionized water.

On the other hand, Fig. 1c shows the XRD pattern of the bulk nickel hydroxide reference catalyst, which was synthesized at room temperature via precipitation using nickel chloride hexahydrate and sodium hydroxide. The bulk nickel hydroxide catalyst exhibited characteristic peaks at $2 \theta=19.20,32.94$, $38.42,52.9,59.19,62.83$, and $72.70^{\circ}$ corresponding to the crystal planes shown in the pattern and can be assigned to the hexagonal crystal system of the $\beta-\mathrm{Ni}(\mathrm{OH})_{2}$ phase (JCPDS: 140117).

The surface morphology of the as-prepared $\mathrm{KNiAlF}_{6}$ catalyst was investigated using scanning electron microscopy (Fig. 2a and b). Clearly, the catalyst exhibits irregular nanosheets morphology with a roughly average thickness of about 60$70 \mathrm{~nm}$ which estimated from the edge of the perpendicularly oriented nanosheets as shown in Fig. S1 (ESI†). On the other hand, the nickel hydroxide reference catalyst prepared at room temperature shows large irregular particles morphology as shown in Fig. 2c.

Fig. 3 shows the X-ray mapping elemental analysis using the SEM images obtained for the $\mathrm{KNiAlF}_{6}$ catalyst. The results confirm the presence of $\mathrm{K}, \mathrm{Ni}, \mathrm{Al}$, and $\mathrm{F}$ at a weight ratio of $11.83,25.62,10.75$, and $51.8 \mathrm{wt} \%$, respectively, which is in good agreement with the molecular formula of $\mathrm{KNiAlF}_{6}$.

\section{Electrochemical characterization of the $\mathrm{KNiAlF}_{6}$ catalyst}

The conductivity of the $\mathrm{KNiAlF}_{6}$ and bulk $\mathrm{Ni}(\mathrm{OH})_{2}$ catalysts was measured using a four-probe conductivity meter using $100 \mu \mathrm{g}$ of each catalyst spread over $1 \mathrm{~cm}^{2}$. The conductivity values obtained for the $\mathrm{KNiAlF}_{6}$ and bulk $\mathrm{Ni}(\mathrm{OH})_{2}$ catalysts were $1.297 \times$ $10^{3}$ and $1.241 \times 10^{2} \mathrm{~S} \mathrm{~m}^{-1}$, respectively. Clearly, the bulk conductivity of the $\mathrm{KNiAlF}_{6}$ nanosheets was almost 10 -fold higher than that observed for bulk $\mathrm{Ni}(\mathrm{OH})_{2}$. The cyclic voltammetry (CV) was performed to investigate the electrochemical behavior of the $\mathrm{KNiAlF}_{6}$ catalyst, as shown in Fig. 4a. The CV study was performed at $50 \mathrm{mV} \mathrm{s}^{-1}$ in $1.0 \mathrm{M} \mathrm{KOH}$ solution using different catalyst loadings $(50,100,200$, and $300 \mu \mathrm{g})$ on the carbon paper support and the results were compared with those of the bulk $\mathrm{Ni}(\mathrm{OH})_{2}$ catalyst (black line).

The cyclic voltammograms reveal the characteristic redox peaks commonly observed for nickel-based catalysts, which originate from the $\mathrm{Ni}(\mathrm{II}) / \mathrm{Ni}(\mathrm{III})$ redox couple,${ }^{34-37}$ as shown in eqn (5).

$$
\mathrm{Ni}(\mathrm{OH})_{2} \leftrightarrow \mathrm{NiOOH}
$$

In the case of the $\mathrm{KNiAlF}_{6}$ catalyst at $100 \mu \mathrm{g}$ loading, the redox peaks are located around 1.45 and $1.25 \mathrm{~V} v s$. HRE for anodic and cathodic reactions, respectively, which are in good agreement with those reported in the literature. ${ }^{34-37}$ On the other hand, for similar catalyst loading the bulk $\mathrm{Ni}(\mathrm{OH})_{2}$ exhibits redox peaks at 1.55 and $1.28 \mathrm{~V}$ for the anodic and cathodic reactions, respectively. The peak separation $(\Delta E)$ of the 


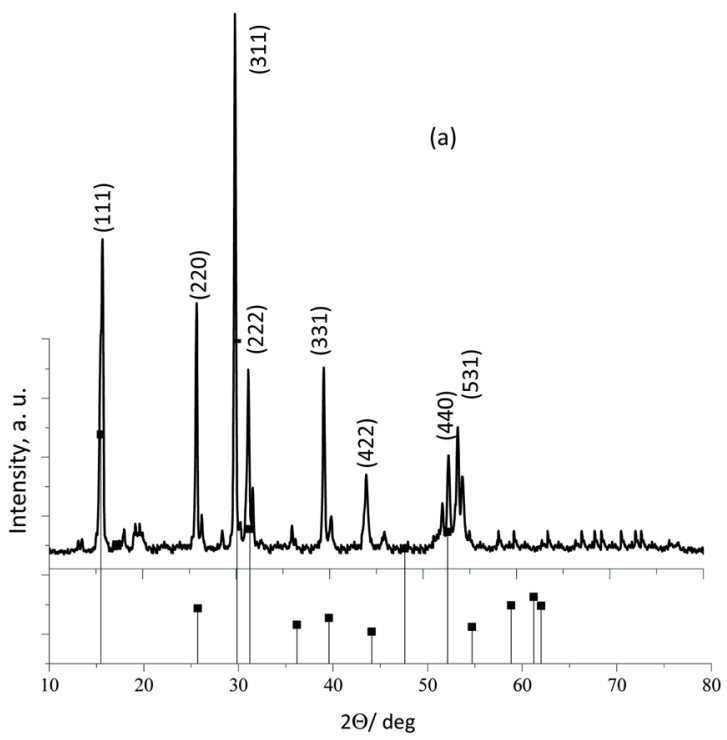

(b)


Fig. 1 (a) Powder X-ray diffraction (PXRD) patterns obtained for the (a) $\mathrm{KNiAlF}_{6}$, (b) the structure of $\mathrm{KNiAlF}_{6}$, the $\left(\mathrm{Ni}_{0.5} \mathrm{Al}_{0.5}\right) \mathrm{F}_{6}$ octahedra are shown in orange, $\mathrm{K}^{+}$cations are large purple spheres and $\mathrm{F}^{-}$ions are green and (c) PXRD pattern of bulk $\mathrm{Ni}(\mathrm{OH})_{2}$ catalysts.
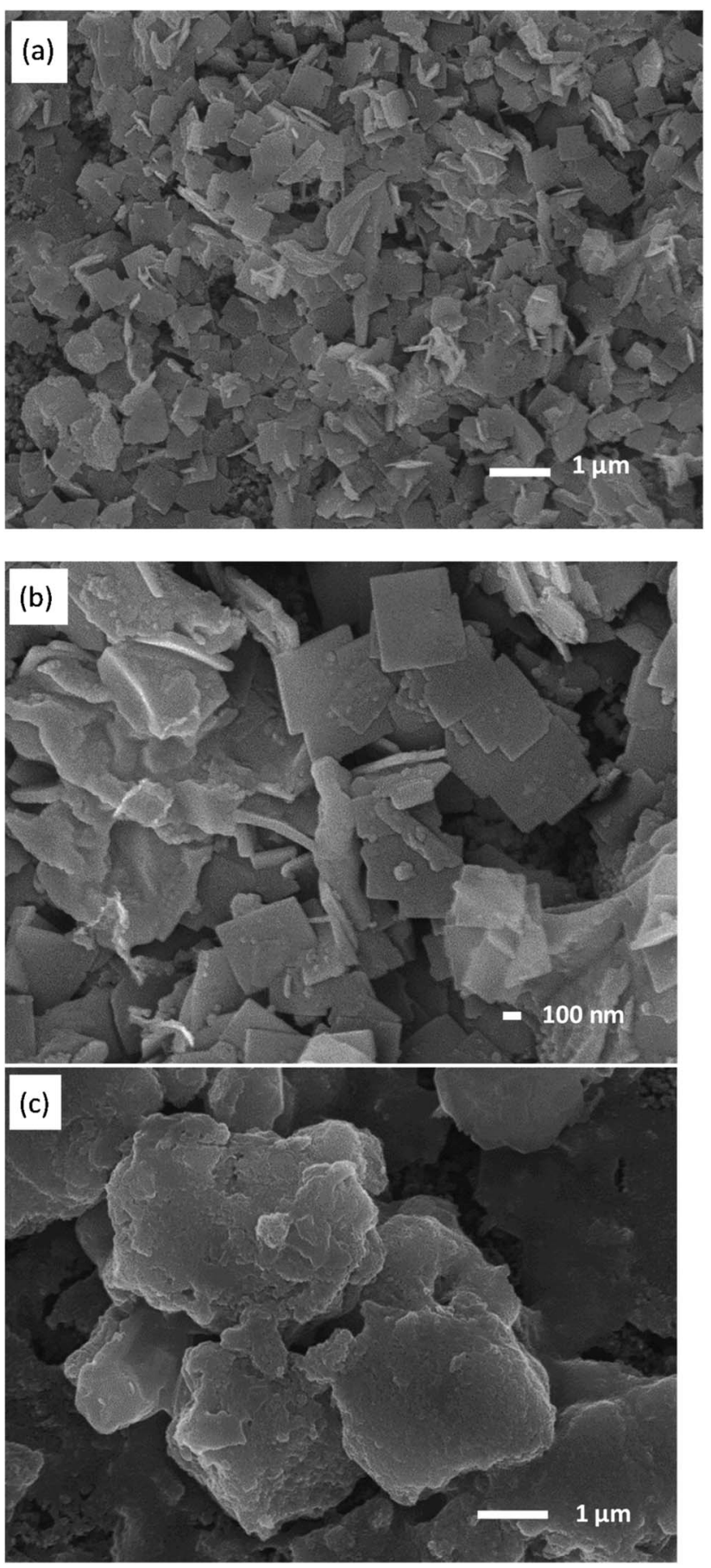

Fig. 2 SEM images recorded at a different magnification of the (a and b) $\mathrm{KNiAlF}_{6}$ and (c) bulk $\mathrm{Ni}(\mathrm{OH})_{2}$ catalysts.

anodic and cathodic reactions $\left(E_{\mathrm{a}}-E_{\mathrm{c}}\right)$ equals 0.20 and $0.27 \mathrm{~V}$ for $\mathrm{KNiAlF}_{6}$ and bulk $\mathrm{Ni}(\mathrm{OH})_{2}$ catalyst respectively which could be correlated to the higher conductivity of the $\mathrm{KNiAlF}_{6}$ nanosheets.

Interestingly the redox peak currents gradually (and linearly) increase upon increasing the catalyst loading, which confirms the existence of the intrinsically active $\mathrm{Ni}(\mathrm{III} / \mathrm{Ni}(\mathrm{III})$ redox centers (Fig. 4b). However, the peak separation $(\Delta E)$ increases upon increasing the catalyst loading, which was attributed to the 

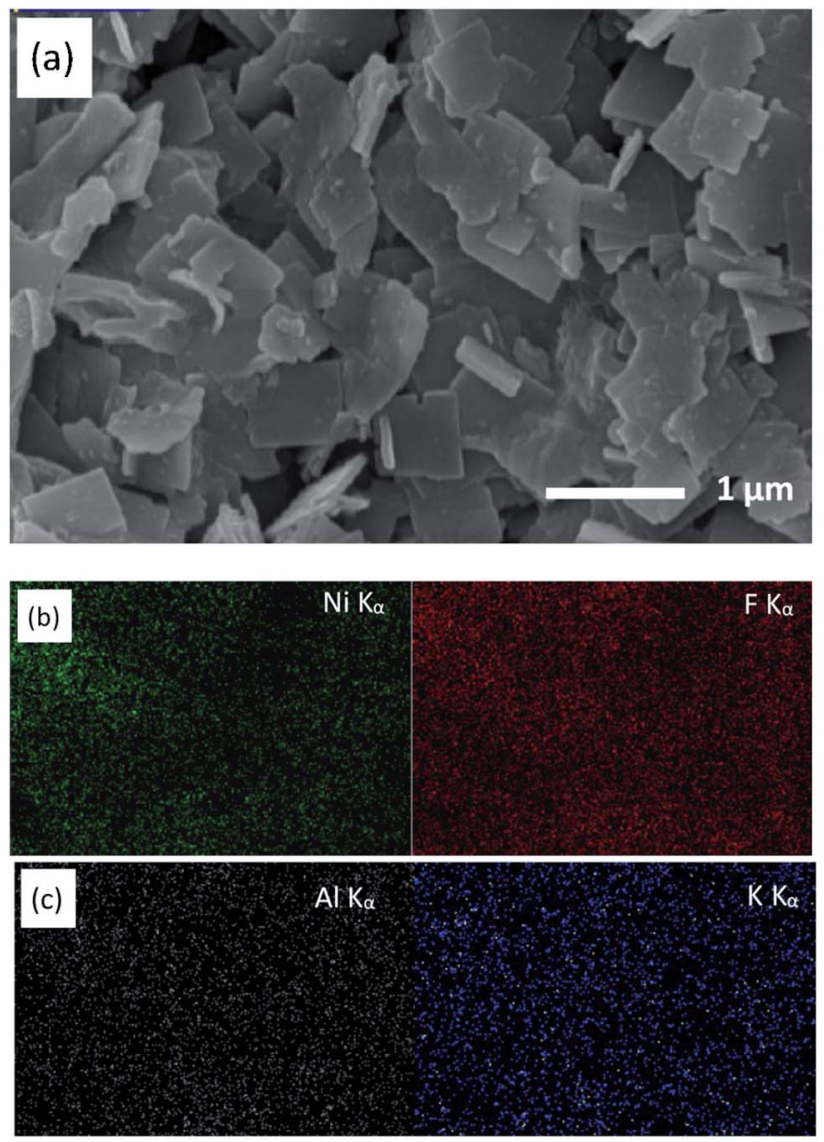

Fig. 3 (a) SEM image and (b and c) corresponding X-ray elemental mapping of the $\mathrm{KNiAlF}_{6}$ catalyst.

reaction being quasi-reversible and the limited diffusion into the thicker film. It is possible to estimate the electroactive surface area (ESA) of the $\mathrm{KNiAlF}_{6}$ catalyst using the charge $(Q)$ area under the reduction peak and eqn (6).

$$
\mathrm{ESA}=Q / m q
$$

where $m$ is the catalyst loading (g) and $q=257 \mu \mathrm{C} \mathrm{cm}^{-2}$, which is related to the charge associated with the monolayer formation of $\mathrm{Ni}(\mathrm{OH})_{2}$ from $\mathrm{NiOOH} .^{18,34,37}$ The $Q$ value refers to the charge required to reduce $\mathrm{NiOOH}$ into $\mathrm{Ni}(\mathrm{OH})_{2}$ during the backward scan, which is normally proportional to the number of exposed active sites comprised of $\mathrm{Ni}(\mathrm{II}) / \mathrm{Ni}$ (III) centers. The ESA obtained for the $\mathrm{KNiAlF}_{6}$ and bulk catalysts were estimated to be 96.99 and $41.07 \mathrm{~m}^{2} \mathrm{~g}^{-1}$. The ESA of $\mathrm{KNiAlF}_{6}$ was significantly higher than bulk $\mathrm{Ni}(\mathrm{OH})_{2}$ presumably due to the presence of higher surface area in the case of the $\mathrm{KNiAlF}_{6}$ nanosheets morphology.

The influence of the $\mathrm{KOH}$ electrolyte concentration on the electrochemical behavior of the $\mathrm{KNiAlF}_{6}$ catalyst was explored using cyclic voltammetry using a catalyst loading of $100 \mu \mathrm{g}$ as illustrated in Fig. 5. The results show that as the $\mathrm{KOH}$ electrolyte concentration increases from 0.1 to $2.0 \mathrm{M}$, the onset potential of the oxidation peak is significantly shifted to a lower potential due to the Nernst effect in which the potential is inversely
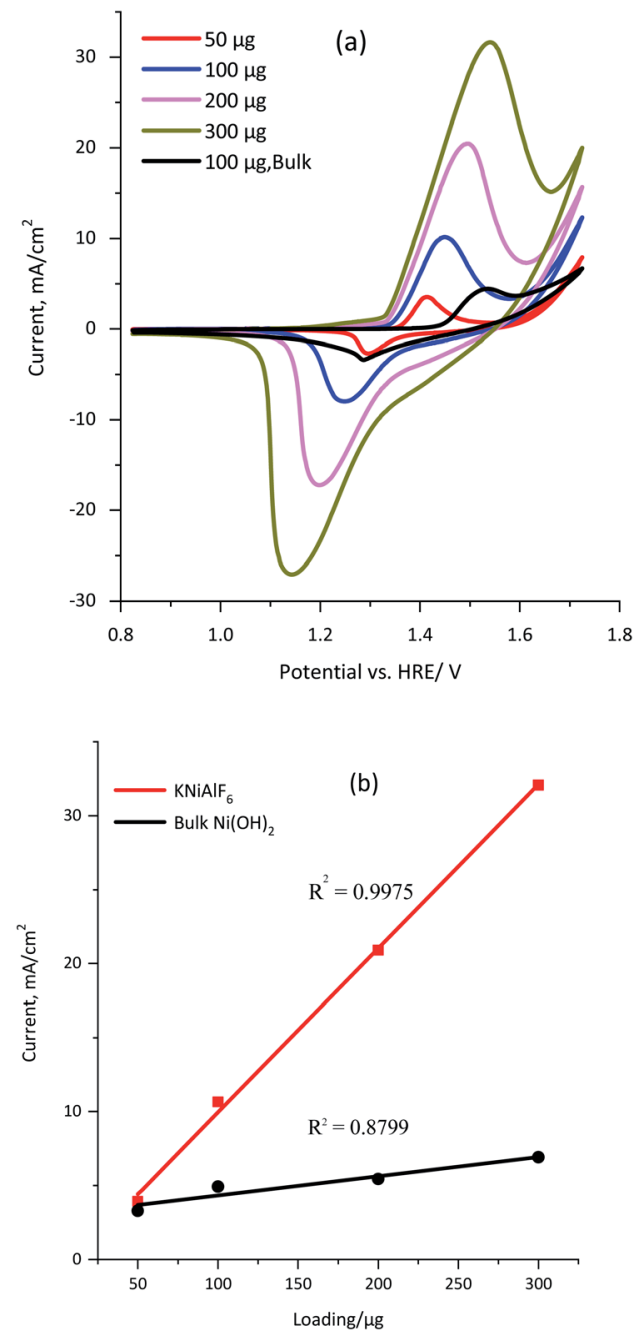

Fig. 4 (a) Cyclic voltammograms obtained for the $\mathrm{KNiAlF}_{6}$ catalyst using various loadings of $50,100,200$, and $300 \mu \mathrm{g}$ in $1.0 \mathrm{M} \mathrm{KOH}$ solution and $100 \mu \mathrm{g}$ of the bulk $\mathrm{Ni}(\mathrm{OH})_{2}$ catalyst (black line) recorded at a scan rate of $50 \mathrm{mV} \mathrm{s}^{-1}$. (b) Relationship between the catalyst loading and current observed for both the $\mathrm{KNiAlF}_{6}$ and bulk $\mathrm{Ni}(\mathrm{OH})_{2}$ catalysts.

proportional to the ion concentration. Therefore, the peak current was increased as the concentration is increased as a result of the increased availability of $\mathrm{OH}$ ions. On the other hand, the bulk $\mathrm{Ni}(\mathrm{OH})_{2}$ reference catalyst exhibits an onset potential of $1.45 \mathrm{~V} v s$. HRE in $1.0 \mathrm{M} \mathrm{KOH}$, which is significantly more positive than the onset potential observed for the $\mathrm{KNiAlF}_{6}$ catalyst $(1.35 \mathrm{~V})$ under similar conditions. This was attributed to the $\mathrm{KNiAlF}_{6}$ nanosheets having higher conductivity compared to bulk $\mathrm{Ni}(\mathrm{OH})_{2}$, which was confirmed by the conductivity measurement (above) and impedance results shown below.

The electrocatalytic activity of $\mathrm{KNiAlF}_{6}$ was compared with that of the bulk $\mathrm{Ni}(\mathrm{OH})_{2}$ catalyst during the electro-oxidation of urea in an alkaline solution using CV and CA. As reported by Botte et al., ${ }^{\mathbf{8 3 8 - 4 0}}$ nickel-based catalysts, in particular metallic nickel, nickel oxides, oxyhydroxides, and phosphates reveal exceptional electrocatalytic activity toward the oxidation of urea due to their redox surface properties and durability. Fig. 6a 


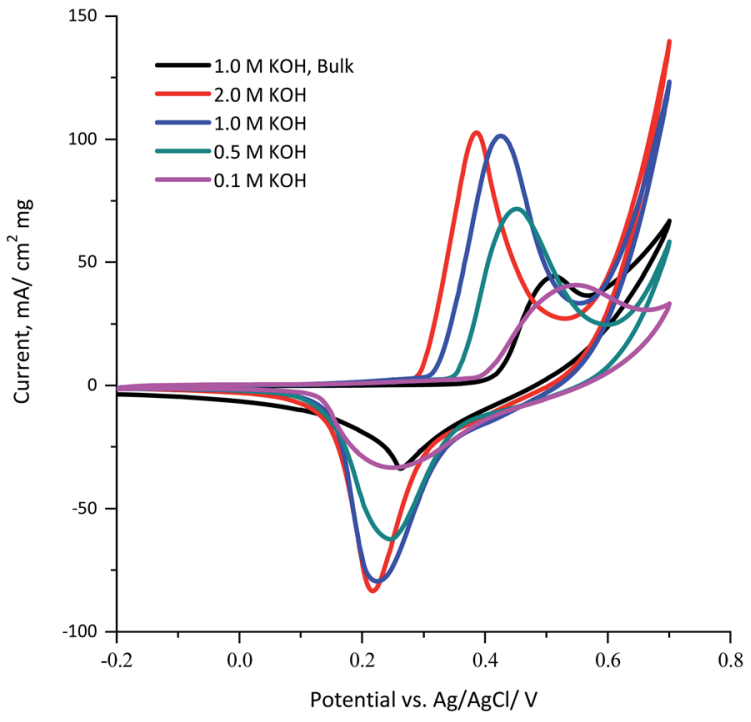

Fig. 5 Cyclic voltammograms obtained for $100 \mu \mathrm{g}$ of the $\mathrm{KNiAlF}_{6}$ and bulk $\mathrm{Ni}(\mathrm{OH})_{2}$ catalysts recorded at a scan rate of $50 \mathrm{mV} \mathrm{s}^{-1}$ in various concentrations of $\mathrm{KOH}$ solution $(0.1,0.5,1.0$, and $2.0 \mathrm{M})$.

shows the $\mathrm{CV}$ recorded at $50 \mathrm{mV} \mathrm{s}{ }^{-1}$ using $100 \mu \mathrm{g}$ of $\mathrm{KNiAlF}_{6}$ in comparison to the bulk $\mathrm{Ni}(\mathrm{OH})_{2}$ catalyst in the presence of different concentrations of urea up to $0.33 \mathrm{M}$ in $1.0 \mathrm{M} \mathrm{KOH}$. The cyclic voltammograms show the presence of the urea oxidation peak around 1.55-1.65 V vs. HRE (Fig. 6a). Moreover, the onset potential for urea oxidation at the $\mathrm{KNiAlF}_{6}$ electrode was located at $\sim 1.35 \mathrm{~V} v$ s. HRE, which was negatively shifted by $\sim 100 \mathrm{mV}$ when compared to the bulk $\mathrm{Ni}(\mathrm{OH})_{2}$ catalyst (black line, Fig. 6a) and could be related to the enhanced electrochemical surface area and the electrical conductivity of $\mathrm{KNiAlF}_{6}$. Besides, the urea oxidation peak current at the $\mathrm{KNiAlF}_{6}$ electrode significantly increases upon increasing the concentration of urea. Further increase of urea concentration above $0.33 \mathrm{M}$ showed a small current enhancement as shown in Fig. $\mathrm{S} 2 \dagger$ possibly because the reaction follows the EC mechanism and the competitive adsorption of urea with hydroxide ion at the catalyst surface decreases the generation rate of $\mathrm{NiOOH}$ species that mediates the urea oxidation in the chemical step. Therefore, an optimum ratio of urea/hydroxide concentration should be maintained to achieve the highest urea oxidation current.

As documented in the literature and shown in eqn (1) and (2) above, the electrochemical oxidation of urea in an alkaline solution using nickel-based electrocatalysts occurs through an indirect electrochemical-chemical (EC') catalyst regeneration reaction mechanism; the active $\mathrm{Ni}($ II) sites are electrochemically oxidized to $\mathrm{Ni}($ III) and then chemically react with urea to regenerate the active $\mathrm{Ni}(\mathrm{II})$ sites. ${ }^{41,42}$ On the other hand, the addition of more urea during the backward scan results in the gradual disappearance of the $\mathrm{Ni}(\mathrm{III} / \mathrm{Ni}$ (II) cathodic peak around $1.30 \mathrm{~V} v s$. HRE. The decrease in the current observed for the $\mathrm{Ni}($ III)/Ni(II) cathodic peak supports the fact that the EC' catalyst regeneration reaction mechanism occurred with a lower amount of $\mathrm{NiOOH}$ available for the reduction step in the backward scan. ${ }^{41}$ In addition, the $\mathrm{KNiAlF}_{6}$ catalyst exhibits an
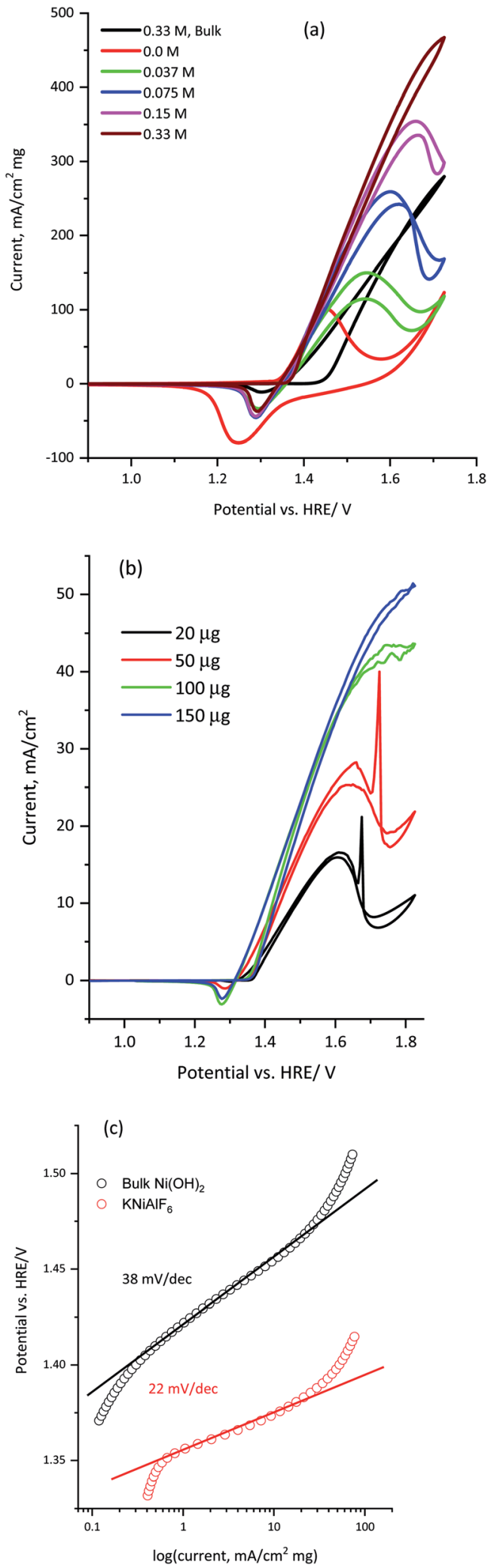

Fig. 6 (a) Cyclic voltammograms obtained for $100 \mu \mathrm{g}$ of the $\mathrm{KNiAlF}_{6}$ and bulk $\mathrm{Ni}(\mathrm{OH})_{2}$ catalysts recorded at $50 \mathrm{mV} \mathrm{s}^{-1}$ in $1.0 \mathrm{M} \mathrm{KOH}$ containing various concentrations of urea $(0.0375,0.075,0.15$, and 0.33 M), (b) cyclic voltammetry obtained for the $\mathrm{KNiAlF}_{6}$ catalyst using different loadings $(20,50,100$, and $150 \mu \mathrm{g})$ recorded at $5 \mathrm{mV} \mathrm{s}^{-1}$ in 1.0 M KOH containing 0.2 M urea, and (c) the corresponding Tafel plot processed from cyclic voltammograms (a) of bulk $\mathrm{Ni}(\mathrm{OH})_{2}$ and $\mathrm{KNiAlF}_{6}$ nanosheets. 

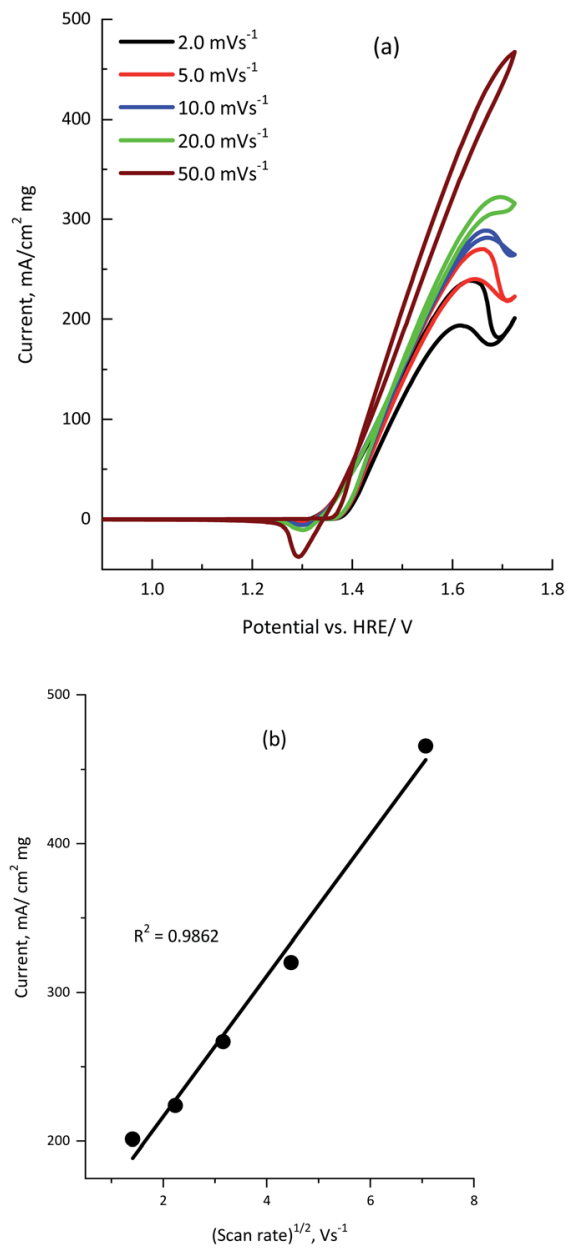

Fig. 7 (a) Cyclic voltammograms obtained for $100 \mu \mathrm{g}$ of the $\mathrm{KNiAlF}_{6}$ catalyst in $1.0 \mathrm{M} \mathrm{KOH}$ solution containing $0.33 \mathrm{M}$ urea recorded at various scan rates $\left(2.0,5.0,10.0,20.0\right.$, and $\left.50.0 \mathrm{mV} \mathrm{s}^{-1}\right)$. (b) The plot of current vs. square root of the scan rate.

increase in the peak current at $1.65 \mathrm{~V} v s$. HRE and reaches $\sim 395$ $\mathrm{mA} \mathrm{cm} \mathrm{cm}^{-1}$ at a urea concentration of $0.33 \mathrm{M}$, while that observed for the bulk $\mathrm{Ni}(\mathrm{OH})_{2}$ catalyst was $238 \mathrm{~mA} \mathrm{~cm}^{-2} \mathrm{mg}^{-1}$.

The effect of the $\mathrm{KNiAlF}_{6}$ catalyst loading on the electrochemical activity of urea oxidation is presented in Fig. 6b. The urea oxidation current gradually increases upon increasing the $\mathrm{KNiAlF}_{6}$ catalyst loading up to $150 \mu \mathrm{g}$ due to the increase in the number of available $\mathrm{Ni}(\mathrm{II}) / \mathrm{Ni}(\mathrm{III})$ active sites responsible for the urea oxidation reaction. However, at a high $\mathrm{KNiAlF}_{6}$ catalyst loading ( $>150 \mu \mathrm{g}$, data not shown) the oxidation current starts to saturate due to the increase in the film thickness and the limited accessibility to the $\mathrm{Ni}(\mathrm{II}) / \mathrm{Ni}$ (III) active sites.

The corresponding Tafel slope of $\mathrm{KNiAlF}_{6}$ and bulk $\mathrm{Ni}(\mathrm{OH})_{2}$ catalysts as obtained from the cyclic voltammograms (Fig. 6a) is shown in Fig. 6c. The obtained Tafel slope in 1.0 $\mathrm{M} \mathrm{KOH}$ and $0.33 \mathrm{M}$ urea solution was equal 22 and $38 \mathrm{mV} \mathrm{dec}^{-1}$ for $\mathrm{KNiAlF}_{6}$ and bulk $\mathrm{Ni}(\mathrm{OH})_{2}$ respectively which indicates much faster reaction kinetics of urea oxidation at $\mathrm{KNiAlF}_{6}$ nanosheets than bulk $\mathrm{Ni}(\mathrm{OH})_{2}$ electrode. This activity and kinetics enhancement can be attributed to the enhanced conductivity and ESA of the
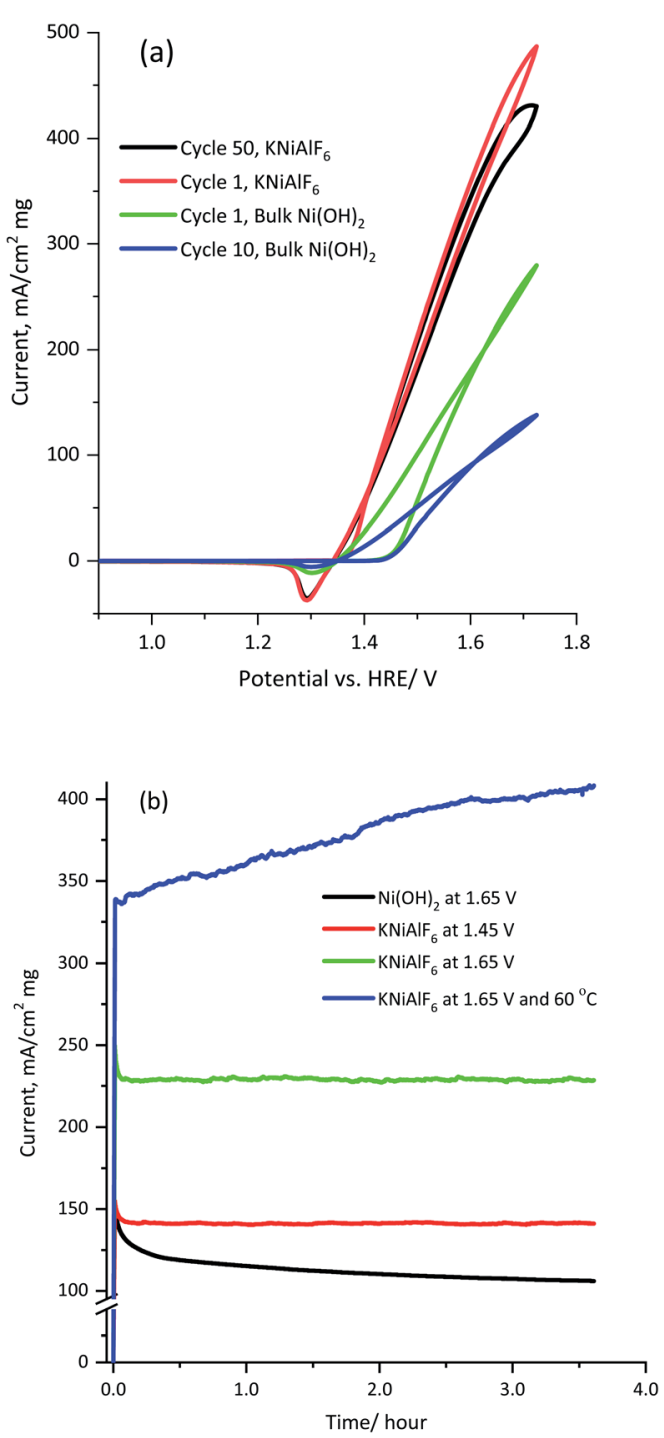

Fig. 8 (a) Multicycles voltammograms obtained for $100 \mu \mathrm{g}$ of the $\mathrm{KNiAlF}_{6}$ and bulk catalysts recorded at $50 \mathrm{mV} \mathrm{s}^{-1}$ in $1.0 \mathrm{M} \mathrm{KOH}$ solution containing $0.33 \mathrm{M}$ urea and (b) the corresponding chronoamperometry recorded at various applied voltages (1.45 and 1.65 vs. $\mathrm{HRE} / \mathrm{V})$ and temperature $\left(25\right.$ and $\left.60^{\circ} \mathrm{C}\right)$.

$\mathrm{KNiAlF}_{6}$ electrode toward the urea oxidation reaction due to the electro-oxidation of the $\mathrm{KNiAlF}_{6}$ catalyst in an alkaline solution toward $\mathrm{NiOOH}$ species that oxidize urea via an EC' mechanism. ${ }^{41}$

Cyclic voltammetry was recorded at various scan rates from 2.0 to $50.0 \mathrm{mV} \mathrm{s}^{-1}$ to investigate the effect of the scan rate on the electro-oxidation of urea using the $\mathrm{KNiAlF}_{6}$ catalyst.

The cyclic voltammograms clearly show that the urea anodic oxidation current increases with the scan rate. In addition, Fig. $7 \mathrm{~b}$ shows the linear relationship observed between the anodic peak current $\left(i_{\text {peak }}\right)$ and the square root of the scan rate $\left[R^{2}=0.9862\right]$, which confirmed the diffusion-controlled urea electro-oxidation reaction occurred using the $\mathrm{KNiAlF}_{6}$ catalyst in an alkaline solution. ${ }^{37,40,41}$ However, the slight shift in the urea wave potential towards a more positive value upon 
Table 1 Comparison of some anodic catalysts in terms of their mass activity during urea oxidation in an alkaline medium (1.0 M KOH)

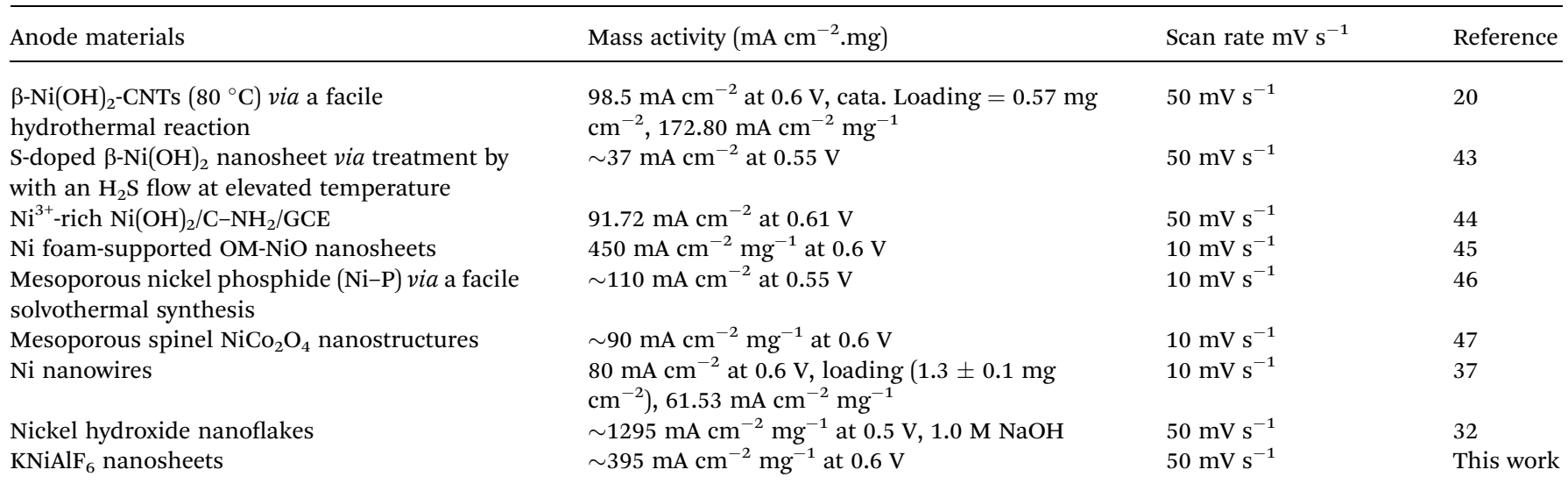

increasing the scan rate could be related to change in the reaction kinetics due to the adsorption of urea molecules on the active $\mathrm{Ni}(\mathrm{III})$ sites at higher scan rates as reported in the literature. ${ }^{39-42}$

Fig. 8 shows the multicycle (50 cycles) and long term chronoamperometry electrolysis of a $1.0 \mathrm{M} \mathrm{KOH}$ solution containing $0.33 \mathrm{M}$ urea using the $\mathrm{KNiAlF}_{6}$ catalyst in comparison to the bulk $\mathrm{Ni}(\mathrm{OH})_{2}$ catalyst at various applied potentials. The cyclic voltammograms of the $\mathrm{KNiAlF}_{6}$ electrode (Fig. 8a) show remarkable stability where the urea oxidation current slightly decreased at $1.65 \mathrm{~V}$ vs. HRE after prolonged cycling. On the other hand, the bulk $\mathrm{Ni}(\mathrm{OH})_{2}$ catalyst exhibits a $\sim 50 \%$ reduction in the urea oxidation current after 50 cycles. In addition, according to chronoamperometry results shown in Fig. 8b and after the double layer capacitance initial current decay, the electrolysis current reaches a steady-state value without any apparent decay during the extended urea electrolysis process at all applied potentials studied.

The electrolysis steady-state current is significantly enhanced upon increasing the applied potential; the $\mathrm{KNiAlF}_{6}$ catalyst mass activity reaches $\sim 230 \mathrm{~mA} \mathrm{~cm}^{-2} \mathrm{mg}^{-1}$ at $1.65 \mathrm{~V} v s$. HRE after 3 hour electrolysis, which is substantially higher than that obtained using the bulk $\mathrm{Ni}(\mathrm{OH})_{2}$ catalyst $\left(\sim 107 \mathrm{~mA} \mathrm{~cm}^{-2}\right.$ $\mathrm{mg}^{-1}$ ). Furthermore, the catalyst stability for urea oxidation was performed at $1.65 \mathrm{~V}$ and $60{ }^{\circ} \mathrm{C}$ as shown in Fig. $8 \mathrm{~b}$ (blue curve). The $\mathrm{KNiAlF}_{6}$ catalyst shows outstanding stability under higher temperature and the urea oxidation current continuously increased recording about $400 \mathrm{~mA} \mathrm{~cm} \mathrm{mg}^{-1}$ after 3 hour electrolysis. This confirmed the superior electrochemical activity and stability of the $\mathrm{KNiAlF}_{6}$ catalyst during urea electrolysis in an alkaline solution compared to those of the bulk $\mathrm{Ni}(\mathrm{OH})_{2}$ catalyst, as well as the that observed for other nickelbased catalysts published in the literature, as shown in Table 1. It worth comparing our $\mathrm{KNiAlF}_{6}$ nanosheets with that of $2 \mathrm{D}$ pure $\mathrm{Ni}(\mathrm{OH})_{2}$ nanosheets catalyst reported by Botte et al. ${ }^{8}$ because of similar nanosheets morphology.

Interestingly as revealed by the cyclic voltammetry study and at similar urea concentration, our $\mathrm{KNiAlF}_{6}$ nanosheets revealed a significant performance $\left(\sim 395 \mathrm{~mA} \mathrm{~cm}^{-2} \mathrm{mg}^{-1}, 1.0 \mathrm{M} \mathrm{KOH}\right)$
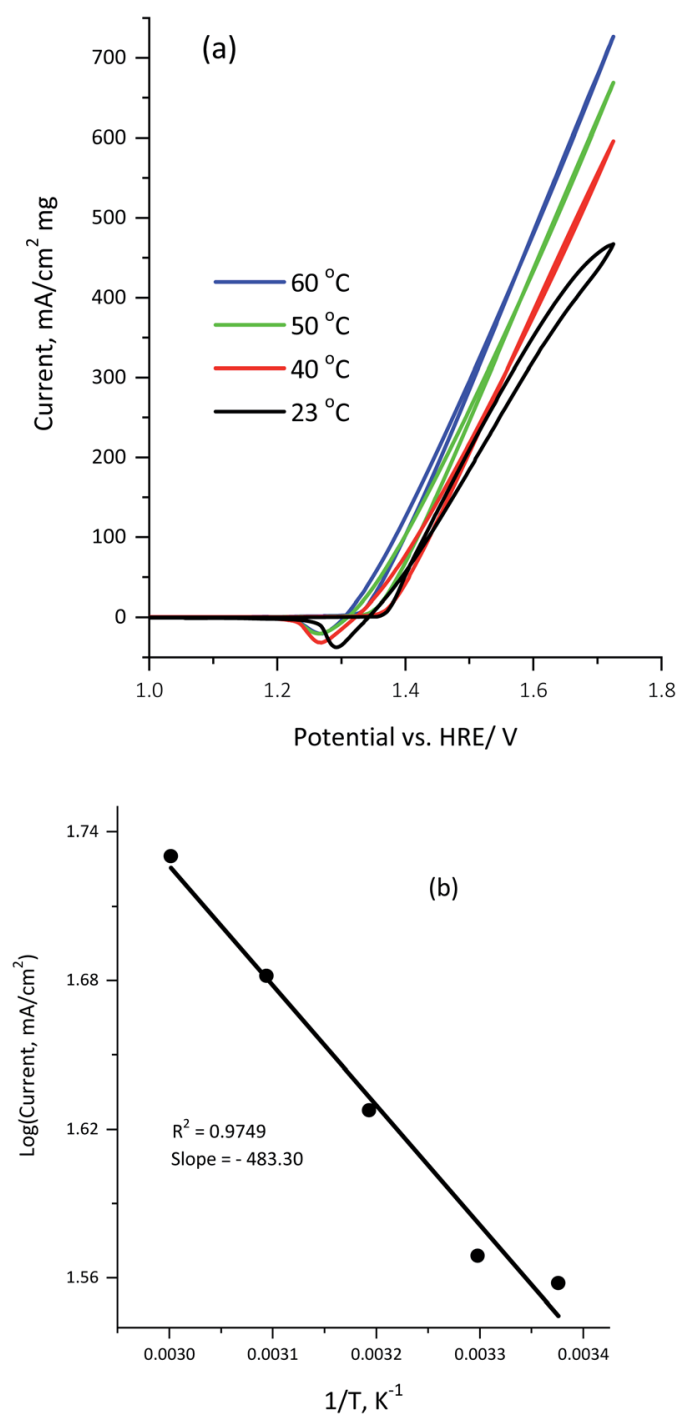

Fig. 9 (a) Cyclic voltammograms obtained for $100 \mu \mathrm{g}$ of the $\mathrm{KNiAlF}_{6}$ catalyst recorded in $0.33 \mathrm{M}$ urea at various temperatures $(23,30,40$, 50 , and $60^{\circ} \mathrm{C}$ ). (b) The plot of the logarithm rate $v s$. the reciprocal of the absolute temperature. 

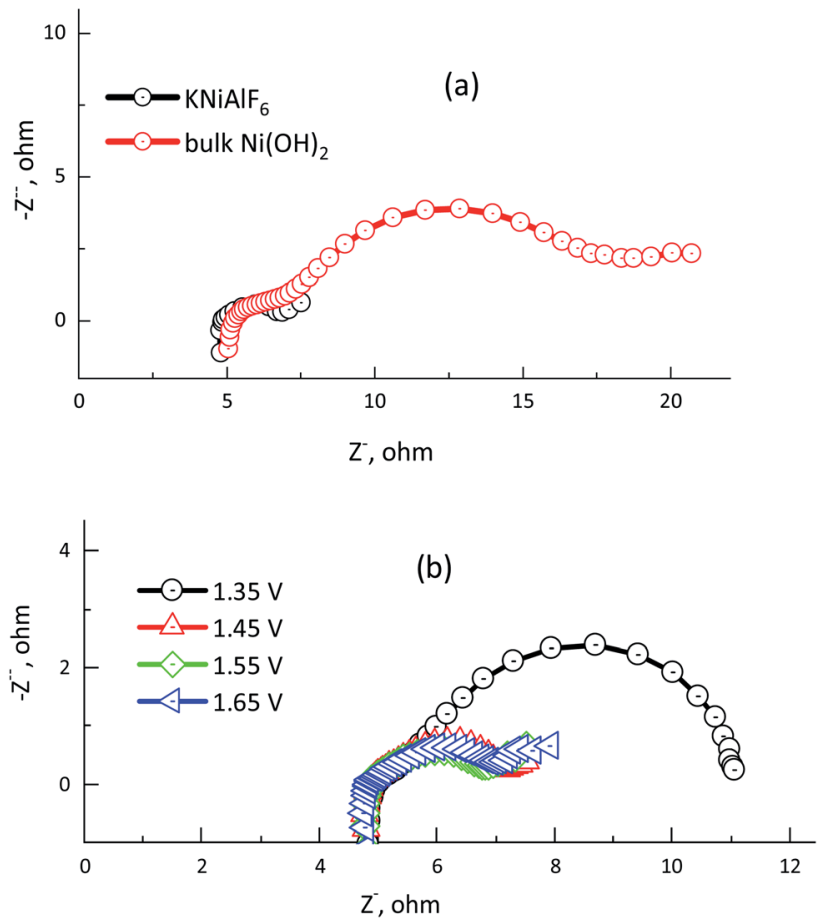

Fig. 10 (a) Nyquist plot obtained for $100 \mu \mathrm{g}$ of the $\mathrm{KNiAlF}_{6}$ and bulk $\mathrm{Ni}(\mathrm{OH})_{2}$ catalysts recorded at $1.65 \mathrm{~V}$ vs. HRE. (b) Nyquist plot obtained for $100 \mu \mathrm{g}$ of the $\mathrm{KNiAlF}_{6}$ catalyst recorded at various potentials: 1.35 , $1.45,1.55$, and $1.65 \mathrm{~V}$ vs. HRE in $1.0 \mathrm{M} \mathrm{KOH}$ solution containing $0.33 \mathrm{M}$ urea.

for urea oxidation in comparison with that of $\mathrm{Ni}(\mathrm{OH})_{2}$ nanosheets $\left(154 \mathrm{~mA} \mathrm{~cm}{ }^{-2} \mathrm{mg}^{-1}, 5.0 \mathrm{M} \mathrm{KOH}\right)$ as reported by Botte et $a l .^{8}$ Moreover from the chronoamperometry study, the mass activity of our $\mathrm{KNiAlF}_{6}$ nanosheets reaches $\sim 230 \mathrm{~mA} \mathrm{~cm}^{-2} \mathrm{mg}^{-1}$ $(1.0 \mathrm{M} \mathrm{KOH})$ while the $\mathrm{Ni}(\mathrm{OH})_{2}$ nanosheets recorded about 100 $\mathrm{mA} \mathrm{cm}^{-2} \mathrm{mg}^{-1}$ in $5.0 \mathrm{M} \mathrm{KOH}$ solution. The electrochemical activity of urea oxidation for our $\mathrm{NiAlF}_{6}$ nanosheets is more than 2 fold higher than that of $\mathrm{Ni}(\mathrm{OH})_{2}$ nanosheet reported by Botte et $a l^{8}$ and this could be related to the better conductivity/ surface area due to the incorporation of aluminum ions in the nickel-based structure frame.

However, the $\mathrm{Ni}(\mathrm{OH})_{2}$ nanoflakes electrocatalyst prepared by liquid crystal template previously reported by Ghanem et al. ${ }^{32}$ showed a higher electrochemical mass activity $\left(\sim 1295 \mathrm{~mA} \mathrm{~cm}^{-2}\right.$ $\mathrm{mg}^{-1}$ ) than the current $\mathrm{KNiAlF}_{6}$ nanosheets catalyst. This presumably because the former catalyst has a higher surface area than the $\mathrm{KNiAlF}_{6}$ nanosheets.

Fig. 9a illustrates the influence of the reaction temperature on the electrocatalytic activity of $100 \mu \mathrm{g}$ of the $\mathrm{KNiAlF}_{6}$ catalyst in a $1.0 \mathrm{M} \mathrm{KOH}$ solution containing $0.33 \mathrm{M}$ urea.

Clearly, the urea electrolysis mass activity observed at $1.65 \mathrm{~V}$ vs. HRE was significantly enhanced upon increasing the temperature increase and reaches $\sim 550 \mathrm{~mA} \mathrm{~cm}^{-2} \mathrm{mg}^{-1}$ at $60{ }^{\circ} \mathrm{C}$ (Fig. 9a). This indicates that the urea oxidation reaction on the $\mathrm{KNiAlF}_{6}$ nanosheets catalyst surface was further activated upon increasing the temperature. Moreover, the onset potential shifts from 1.35 to $1.31 \mathrm{~V}$ vs. HRE upon increasing the temperature from 23 to $60{ }^{\circ} \mathrm{C}$ whilst maintaining the $\mathrm{Ag} / \mathrm{AgCl}$ reference electrode at room temperature $\left(23^{\circ} \mathrm{C}\right)$. Furthermore, the apparent activation energy for urea electro-oxidation using the $\mathrm{KNiAlF}_{6}$ catalyst in $0.33 \mathrm{M}$ urea/1.0 $\mathrm{M} \mathrm{KOH}$ can be calculated by plotting the logarithm of current density $v s$. reciprocal of the absolute temperature, as shown in Fig. 9b. According to the Arrhenius equation (eqn (7)), ${ }^{37,48,49}$ the plot points are reasonably fitted by a straight line with the correlation coefficient is very close to unity $\left(R^{2}=0.974\right)$, where $K$ is the reaction rate constant, $A$ is the Arrhenius constant, $E_{\mathrm{a}}$ is the activation energy, $R$ is the gas constant, and $T$ is the absolute temperature.

$$
K=A \mathrm{e}^{-E_{\mathrm{a}} / R T}
$$

The value obtained for the activation energy $\left(E_{\mathrm{a}}\right)$ from the slope of the straight line was found to be $4.02 \mathrm{~kJ} \mathrm{~mol}^{-1}$, which is significantly low when compared to for example nickel-based nanosheets grown on reduced graphene support $\left(10.35 \mathrm{~kJ} \mathrm{~mol}^{-1}\right)$ and those reported in other published studies related to urea oxidation on nickel-based materials ${ }^{50,51}$ and methanol oxidation. ${ }^{49,52}$

Electrochemical impedance spectroscopy (EIS) was used to determine the electrode/electrolyte interface charge resistance of the electrochemical urea oxidation reaction using the $\mathrm{KNiAlF}_{6}$ catalyst in comparison with that of bulk $\mathrm{Ni}(\mathrm{OH})_{2}$ catalyst in $1.0 \mathrm{M} \mathrm{KOH}$ and in the presence of $0.33 \mathrm{M}$ urea. Fig. 10a and b show the Nyquist plots obtained for the $\mathrm{KNiAlF}_{6}$ nanosheets and bulk $\mathrm{Ni}(\mathrm{OH})_{2}$ catalysts at $1.65 \mathrm{~V}$ and the EIS measurements recorded at various potentials $(1.35-1.65 \mathrm{~V} v s$. HRE), respectively. As shown in the inset in Fig. 10a, the impedance spectra obtained for the $\mathrm{KNiAlF}_{6}$ nanosheets and bulk $\mathrm{Ni}(\mathrm{OH})_{2}$ catalysts can be fitted to an equivalent circuit

Table 2 EIS parameters including $R_{\mathrm{s}}, R_{\mathrm{ct} 1}, R_{\mathrm{ct} 2}, \mathrm{CPE} 1, \mathrm{CPE} 2$, and Warburg elements obtained for the $\mathrm{KNiAlF}_{6}$ nanosheet and bulk Ni(OH) 2 catalysts recorded at various potentials in $1.0 \mathrm{M} \mathrm{KOH}$ solution containing $0.33 \mathrm{M}$ urea

\begin{tabular}{|c|c|c|c|c|c|c|}
\hline \multirow{2}{*}{$\begin{array}{l}\text { Potential } v s \text {. } \\
\text { HRE (V)/catalyst }\end{array}$} & \multicolumn{6}{|c|}{ ISE parameters } \\
\hline & $R_{\mathrm{S}}$ & $R_{\mathrm{ct} 1}(\Omega)$ & $\operatorname{CPE} 1\left(Q_{1}\right)$ & $R_{\mathrm{ct} 2}(\Omega)$ & $\operatorname{CPE} 2\left(Q_{2}\right)$ & Warburg \\
\hline 1.65/Bulk & 5.30 & 1.37 & $2.129 \times 10^{-4}$ & 12.61 & 0.0103 & 0.125 \\
\hline $1.65 / \mathrm{KNiAlF}_{6}$ & 4.88 & 1.866 & 0.0219 & 0.239 & 0.00159 & 1.659 \\
\hline $1.55 / \mathrm{KNiAlF}_{6}$ & 4.88 & 0.223 & 0.0014 & 1.662 & 0.02361 & 1.958 \\
\hline $1.45 / \mathrm{KNiAlF}_{6}$ & 4.89 & 1.906 & 0.0199 & 0.303 & 0.00154 & 3.323 \\
\hline $1.35 / \mathrm{KNiAlF}_{6}$ & 5.00 & 0.796 & 0.0114 & 5.39 & 0.01687 & $9.447 \times 10^{11}$ \\
\hline
\end{tabular}


model involving a series combination of ohmic resistance $\left(R_{\mathrm{S}}\right)$, a generalized finite Warburg resistance with its short circuit $\left(R_{\mathrm{ct} 1}-\mathrm{W} \| \mathrm{CPE} 1\right)$. The high frequency relates to the $\mathrm{Ni}(\mathrm{OH})_{2} /$ $\mathrm{NiOOH}$ reaction involving indirect urea oxidation, which is connected in series with the parallel resistance-constant phase elements ( $R_{\mathrm{ct} 2}$ and CPE2, respectively) and at a low frequency associated with the direct urea electro-oxidation reaction. The equivalent circuit model is shown in the inset of Fig. 10a is similar to those previously reported for the electrochemical urea oxidation reaction. ${ }^{36,53,54}$ The constant phase element (CPE) corresponds to the double-layer capacitance and was used to replace the pure capacitor based on previously reported models, which attribute the CPE to the frequency distribution of the capacitance. This replacement may arise due to the electrode surface inhomogeneity, roughness, reactivity, porosity, and surface/normal distribution of the electrode elements. ${ }^{55}$

Fig. 10a shows the radii of the arc observed in the EIS Nyquist plots obtained for the $\mathrm{KNiAlF}_{6}$ electrode are lower than those of the bulk $\mathrm{Ni}(\mathrm{OH})_{2}$ catalyst, which indicates that the $\mathrm{KNiAlF}_{6}$ catalyst possesses a smaller $R_{\text {ct }}$ indicating higher electrode conductivity and enhanced electrochemical urea oxidation performance. Table 2 clearly shows that the resistor $\left(R_{\mathrm{s}}\right)$ representing the electrolyte resistance stays almost constant with an average value of $4.9 \Omega$, while the $R_{\mathrm{ct} 2}$ values observed for the $\mathrm{KNiAlF}_{6}$ nanosheets and bulk $\mathrm{Ni}(\mathrm{OH})_{2}$ electrodes were found to be 1.662 , and $12.61 \Omega$, respectively. The $R_{\mathrm{ct} 2}$ values for the second semicircle (corresponding to the direct urea electrooxidation reaction) at various polarization potentials are plotted in Fig. 10b and the corresponding impedance parameters are summarized in Table 2. It can be seen that the semicircle diameter and $R_{\text {ct2 } 2}$ values are significantly decreased as the oxidation potential was shifted from 1.35 to $1.65 \mathrm{~V} v$ s. HRE, which suggests that the urea electro-oxidation process at the $\mathrm{KNiAlF}_{6}$ nanosheet electrode is significantly improved at higher potential, which is consistent with the cyclic voltammetry results.

After the chronoamperometry measurement of the urea electrolysis process, the used $\mathrm{KNiAlF}_{6}$ catalyst was characterized using XRD and scanning electron microscopy to identify the changes in the $\mathrm{KNiAlF}_{6}$ catalyst crystal structure and surface morphology. Fig. 11a shows the XRD pattern obtained for the $\mathrm{KNiAlF}_{6}$ catalyst after being used in the urea electrochemical electrolysis process in $0.33 \mathrm{M}$ urea/1.0 M KOH solution at $0.6 \mathrm{~V}$ for 3 hours at $23{ }^{\circ} \mathrm{C}$. The XRD pattern revealed that the peaks match the characteristic peaks for both crystalline $\mathrm{KNiAlF}_{6}$ (JPC: 01-072-1553) and amorphous $\mathrm{Ni}(\mathrm{OH})_{2} / \mathrm{NiOOH}$ (JPC: 01-0897111), which confirms the partial transformation of $\mathrm{KNiAlF}_{6}$ to $\mathrm{Ni}(\mathrm{OH})_{2} / \mathrm{NiOOH}$ during the urea electrolysis process and the electrochemical reaction with the $1.0 \mathrm{M} \mathrm{KOH}$ solution. Fig. 11b and $\mathrm{c}$ show the SEM images of the $\mathrm{KNiAlF}_{6}$ nanosheets surface morphology after been used in urea electrolysis process that conducted at $1.65 \mathrm{~V}$ in $0.33 \mathrm{M}$ urea/1.0 $\mathrm{M} \mathrm{KOH}$ solution for three hours at 23 and $60{ }^{\circ} \mathrm{C}$, respectively. Interestingly, the SEM images reveal a significant change in the $\mathrm{KNiAlF}_{6}$ nanosheets morphology where the nanosheets are swelled and coalesced forming a continuous structure. However, the nanosheets' edges are still observable to some extent and the catalyst
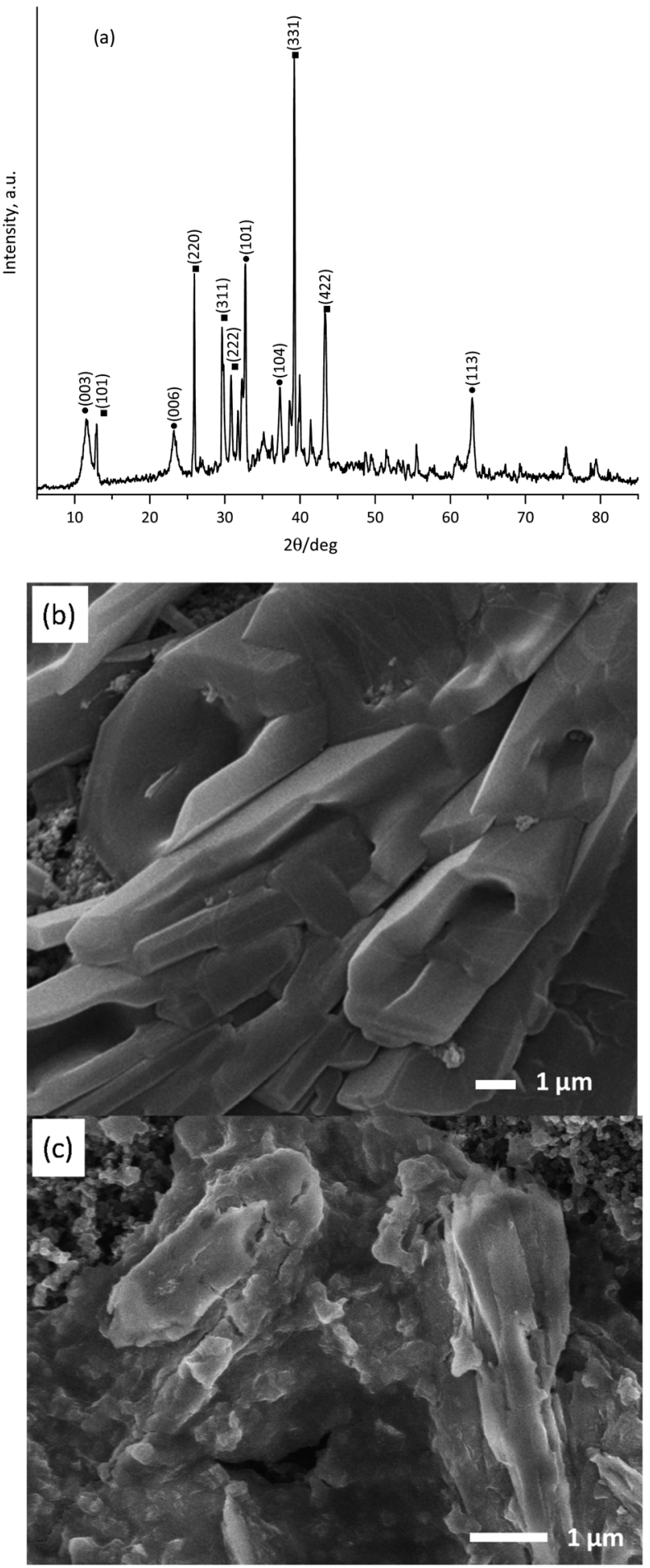

Fig. 11 (a) Powder X-ray diffraction pattern obtained for the $\mathrm{KNiAlF}_{6}$ catalyst after being used in the electrolysis in $1.0 \mathrm{M} \mathrm{KOH}$ solution containing $0.33 \mathrm{M}$ urea performed at $1.65 \mathrm{~V}$ vs. HRE for 3 hours, (b) SEM images of the $\mathrm{KNiAlF}_{6}$ catalyst after being used in the electrolysis of a $1.0 \mathrm{M} \mathrm{KOH}$ solution containing $0.33 \mathrm{M}$ urea performed at $1.65 \mathrm{~V}$ vs. $\mathrm{HRE}$ for $3 \mathrm{~h}$ at $25^{\circ} \mathrm{C}$ and (c) at $60^{\circ} \mathrm{C}$.

maintained its electrocatalytic activity for urea oxidation as shown above by chronoamperometry in Fig. 8b. The corresponding X-ray elemental mapping and composition wt $\%$ of the 
$\mathrm{KNiAlF}_{6}$ catalyst after been used in urea oxidation at $60{ }^{\circ} \mathrm{C}$ for 3.0 hours are shown in Fig. S3 and Table S1† respectively. The EDX composition analysis of the $\mathrm{KNiAlF}_{6}$ catalyst shows the $\mathrm{wt} \%$ of $\mathrm{K}, \mathrm{Al}$, and $\mathrm{Ni}$ is slightly changed after been used in urea electrolysis. On the other hand, fluorine percentage is significantly decreased from 51.8 to $28.55 \mathrm{wt} \%$ while oxygen has been increased to $28.27 \mathrm{wt} \%$. The element composition change could be related to the partial change in the phase structure of $\mathrm{KNiAlF}_{6}$ to $\mathrm{Ni}(\mathrm{OH})_{2} / \mathrm{NiOOH}$ after the catalyst been used in urea oxidation as confirmed by the X-ray results shown in Fig. 11a.

\section{Conclusions}

In summary, the catalyst of $\mathrm{KNiAlF}_{6}$ nanosheets was successfully prepared using solid-phase synthesis and employed as an electrocatalyst for urea electrolysis conducted in alkaline media. The crystal structure, morphology, conductivity, and composition analysis has been carefully characterized and the results revealed that the formation of $\mathrm{KNiAlF}_{6}$ nanosheets with cubic defect pyrochlore structure and roughly average thickness of 60$70 \mathrm{~nm}$ and conductivity of $1.297 \times 10^{3} \mathrm{~S} \mathrm{~m}^{-1}$. The obtained $\mathrm{KNiAlF}_{6}$ nanosheets catalyst exhibited significantly enhanced conductivity and electrochemical activity during the urea oxidation reaction in alkaline media. Urea oxidation peak current of $\sim 395 \mathrm{~mA} \mathrm{~cm} \mathrm{mg}^{-1}$ at $1.65 \mathrm{~V} v s$. HRE, oxidation onset potential of $1.35 \mathrm{~V} v s$. HRE and Tafel slope of $22 \mathrm{mV} \mathrm{dec}^{-1}$, reaction activation energy of $4.02 \mathrm{~kJ} \mathrm{~mol}^{-1}$ and, steady-state mass activity of 230 and $107 \mathrm{~mA} \mathrm{~cm} \mathrm{mg}^{-1}$ were achieved. Low charge transfer resistance and long-term urea oxidation durability at higher temperature of the $\mathrm{KNiAlF}_{6}$ nanosheets are revealed from the impedance and chronoamperometry characterizations. After the catalyst is been used in urea oxidation, the crystal structure and surface morphology of the $\mathrm{KNiAlF}_{6}$ nanosheets were significantly changed due to the partial transformation to $\mathrm{Ni}(\mathrm{OH})_{2} / \mathrm{NiOOH}$ structure, however, the electrochemical activity was maintained during the extended use in the urea electrolysis process.

\section{Conflicts of interest}

The authors declare no conflict of interest.

\section{Acknowledgements}

The authors are grateful to the Deanship of Scientific Research at King Saud University for funding this research group No. RG1437-015 and thank the Researchers Support \& Services Unit (RSSU) for the manuscript proofreading. S. Aladeemy thanks the students support program provided by K.A.CARE.

\section{Notes and references}

1 I. Staffell, D. Scamman, A. V. Abad, P. Balcombe, P. E. Dodds, P. Ekins, N. Shahd and K. R. Warda, Energy Environ. Sci., 2019, 12, 463.

2 W. Zhang, W. Lai and R. Cao, Chem. Rev., 2017, 117, 3717. 3 W. Xu, Z. Wu and S. Tao, Energy Technol., 2016, 4, 1329.
4 P. Joghee, J. N. Malik, S. Pylypenko and R. O'Hayre, MRS Energy Sustain., 2015, 2, 1-31.

5 B. K. Boggs, R. L. King and G. G. Botte, Chem. Commun., 2009, 32, 4859-4861.

6 J. C. Wright, A. S. Michaels and A. J. Appleby, AIChE J., 1986, 32, 1450-1458.

7 W. Simka, J. Piotrowski and G. Nawrat, Electrochim. Acta, 2007, 52, 5696-5703.

8 D. Wang, W. Yan and G. G. Botte, Electrochem. Commun., 2011, 13, 1135-1138.

9 W. Yan, D. Wang and G. G. Botte, Electrochim. Acta, 2012, 61, 25-30.

10 E. Taha, S. T. Eisa, H. O. Mohamed, M. A. Abdelkareem, A. Allaguid, H. Alawadhib and K.-J. Chae, J. Power Sources, 2019, 417, 159.

11 R. Lan, S. Tao and J. T. S. Irvine, Energy Environ. Sci., 2010, 3, 438.

12 W. Yan, D. Wang and G. G. Botte, Appl. Catal., B, 2012, 127, 221.

13 D. Wang, W. Yan, S. H. Vijapur and G. G. Botte, Electrochim. Acta, 2013, 89, 732.

14 W. Huang, H. Wang, J. Zhou, J. Wang, P. Duchesne, D. Muir, P. Zhang, N. Han, F. Zhao, M. Zeng, J. Zhong, C. Jin, Y. Li, S. Lee and H. Dai, Nat. Commun., 2015, 6, 10035.

15 A. M. Al-Enizia, M. A. Ghanem, A. A. El-Zatahry and S. S. AlDeyab, Electrochim. Acta, 2014, 137, 774.

16 J. Li, Y. Zuo, J. Liu, X. Wang, X. Yu, R. Du, T. Zhang, M. F. Infante-Carrió, P. Tang, J. Arbiol, J. Llorca, Z. Luo and A. Cabot, J. Mater. Chem. A, 2019, 7, 22036.

17 D. Wang, W. Yan, S. H. Vijapur and G. G. Botte, Electrochim. Acta, 2013, 89, 732.

18 S. Periyasamy, P. Subramanian, E. Levi, D. Aurbach, A. Gedanken and A. Schechter, ACS Appl. Mater. Interfaces, 2016, 8, 12176.

19 M. Mazloum-Ardakani, V. Eslami and A. Khoshroo, Mater. Sci. Eng., B, 2018, 229, 201.

20 Q. Gan, X. Cheng, J. Chen, D. Wang, B. Wang, J. Tain, T. Isimjan and X. Yang, Electrochim. Acta, 2019, 301, 47.

21 W. Yan, Nickel-based Catalysts for Urea Electro-oxidation, PhD thesis, Ohio University, 2014.

22 X. Guo, H. Liu, Y. Xue, J. Chen, X. Wan, J. Zhang, Y. Liu, A. Yuan, Q. Kong and H. Fan, Eur. J. Inorg. Chem., 2019, 32, 3719.

23 J. Huang, D. Cao, T. Lei, S. Yang, X. Zhou, P. Xu and G. Wang, Electrochim. Acta, 2013, 111, 713.

24 A. Béléké and M. Mizuhata, J. Power Sources, 2010, 195, 7669. 25 C. Faure, C. Delmas, M. Fouassier and P. Willmann, J. Power Sources, 1991, 35, 249.

26 S. Chou, F. Cheng and J. Chen, Eur. J. Inorg. Chem., 2005, 2005, 4035.

27 L. Guerlou-Demourgues, C. Tessier, P. Bernard and C. Delmas, J. Mater. Chem., 2004, 14, 2649.

28 C. Lin, Z. Gao, F. Zhang, J. Yang, B. Liu and J. Jin, J. Mater. Chem. A, 2018, 6, 13867.

29 M. A. Abdelkareem, Y. Al Haj, M. Alajami, H. Alawadhi and N. A. M. Barakat, J. Environ. Chem. Eng., 2018, 6, 332. 
30 N. A. M. Barakat, H. M. Moustafa, M. M. Nassar, M. A. Abdelkareem, M. S. Mahmoud, A. A. Almajid and K. A. Khalil, Electrochim. Acta, 2015, 182, 143.

31 R. M. Abdel Hameed and S. S. Medany, J. Colloid Interface Sci., 2017, 508, 291.

32 M. A. Ghanem, A. M. Al-Mayouf, J. P. Singh and P. Arunachalam, Electrocatal, 2017, 8, 16.

33 D. Babel, G. Pausewang and W. Viebahn, Z. Naturforsch. Teil B Anorg. Chem. Org. Chem. Biochem. Biophys. Biol., 1967, 22, 1219.

34 M. Alsabet, M. Grdeń and G. Jerkiewicz, Electrocatal, 2015, 6, 60.

35 Y. J. Shih, Y. H. Huang and C. P. Huang, Electrochim. Acta, 2018, 263, 261.

36 F. Guo, K. Ye, M. Du, X. Huang, K. Cheng, G. Wang and D. Cao, Electrochim. Acta, 2016, 210, 474.

37 W. Yan, D. Wang, L. A. Diaz and G. G. Botte, Electrochim. Acta, 2014, 134, 266.

38 V. Vedharathinam and G. G. Botte, J. Phys. Chem. C, 2014, 118, 21806-21812.

39 D. A. Daramola, D. Singh and G. G. Botte, J. Phys. Chem. A, 2010, 114, 11513.

40 D. Wang, W. Yan, S. H. Vijapur and G. G. Botte, J. Power Sources, 2012, 217, 498.

41 V. Vedharathinam and G. G. Botte, Electrochim. Acta, 2012, 81, 292.

42 E. Lohrasbi and M. Asgari, Adv. Anal. Chem., 2015, 5, 9.
43 X. Zhu, X. Dou, J. Dai, X. An, Y. Guo, L. Zhang, S. Tao, J. Zhao, W. Chu, X. C. Zeng, C. Wu and Y. Xie, Angew. Chem., Int. Ed., 2016, 55, 12465.

44 D. Wang, S. Liu, Q. Gan, J. Tian, T. T. Isimjan and X. Yang, J. Electroanal. Chem., 2018, 829, 81.

45 M. S. Wu, G. W. Lin and R. S. Yang, J. Power Sources, 2014, 272, 711.

46 R. Ding, X. Li, W. Shi, Q. Xu, L. Wang, H. Jiang, Z. Yang and E. Liu, Electrochim. Acta, 2016, 222, 455.

47 R. Ding, L. Qi, M. Jia and H. Wang, Nanoscale, 2014, 6, 1369.

48 N. Radenahmad, A. Afif, P. I. Petra, S. M. H. Rahman, S. G. Eriksson and A. K. Azad, Renewable Sustainable Energy Rev., 2016, 57, 1347.

49 J. L. Cohen, D. J. Volpe and H. D. Abruña, Phys. Chem. Chem. Phys., 2007, 9, 49.

50 A. Zaher, W. M. A. El Rouby and N. A. M. Barakat, Int. J. Hydrogen Energy, 2020, 45, 8082.

51 B. Li, C. Song, J. Jun, Y. Ke, Y. Kui, C. Kaizhu, D. Cao and G. Wang, Int. J. Hydrogen Energy, 2020, 45, 10569.

52 A. Nouralishahi, Y. Mortazavi, A. A. Khodadadi, M. Choolaei, L. T. Thompson and B. A. Horri, Appl. Surf. Sci., 2019, 335, 467.

53 R. K. Singh and P. Subramanian, ChemElectroChem, 2017, 4, 1037.

54 R. M. Abdel Hameed and S. S. Medany, J. Colloid Interface Sci., 2018, 513, 536.

55 R. K. Singh, R. Devivaraprasad, T. Kar, A. Chakraborty and M. Neergat, J. Electrochem. Soc., 2015, 162, F489. 